\title{
Research on the Characteristics of Innovation in Small and Medium Sized Enterprises: A Comparative Analysis of Large Enterprises
}

\author{
Shouyu Chen \\ Zhejiang Yuexiu University of Foreign Languages, Shaoxing, P.R.China \\ chenshyu@zju.edu.cn
} Keywords: Small and Medium Enterprises (SMEs); The characteristics of innovation; Comparative
analysis; Behavior advantage; Resource inferiority

\begin{abstract}
The number of small and medium-sized enterprises (SMEs) is huge, and the innovation of SMEs is of great significance to economic development. The innovation of SMEs is different from large enterprises, and has its own characteristics. The most important advantage of small and medium-sized enterprise innovation is behavior advantage, the biggest disadvantage lies in resource inferiority. It is of practical significance in guiding SMEs' innovative activities to fully understand the characteristics of SMEs' innovation.
\end{abstract}

\section{Introduction}

The innovations of different types of organizations reflect their internal and external environment. Because of the different internal and external environment, it leads to the difference of innovation among different types of organizations. Small and medium-sized enterprises and large enterprises are often affected by different internal and external environments because of their different organizational sizes, thus showing different characteristics of innovation and obstacles to innovation. Compared to large enterprises, small and medium-sized enterprises have both advantages and disadvantages in innovation. Understanding the characteristics and obstacles of SMEs in the process of innovation can promote successful innovation activities of SMEs.

\section{The Definition of SMEs}

The biggest difference between SMEs and large enterprises is the number of employees [1]. For the definition of small and medium-sized enterprises is mainly by the number of employees in different countries or regions.

Table 1 The classification standard of SMEs

\begin{tabular}{l|l}
\hline \multirow{5}{*}{ CHINA } & $\begin{array}{l}\text { Ministry of industry and information technology have defined SMEs according to } \\
\text { different industries. Take industry as an example, SMEs include the firms which } \\
\text { employed } 1000 \text { people or less, or less than } 400 \text { million yuan of income. Among them, } \\
\text { medium-sized enterprises have more than } 300 \text { employees, and operating income of } 20 \\
\text { million yuan or above; small businesses have more than } 20 \text { employees, and operating } \\
\text { income of more than } 3 \text { million yuan; micro enterprises employ } 20 \text { people or operating } \\
\text { income of } 3 \text { million yuan. See the regulation of small and medium enterprises (2011). }\end{array}$ \\
\hline \multirow{5}{*}{ USA } & $\begin{array}{l}\text { According to the number of sales or employees of different industries, the U.S. Small } \\
\text { Business Administration (SBA) define the types of small businesses. Most of the } \\
\text { manufacturing enterprises is divided by the number of employees, for example, most } \\
\text { manufacturing enterprises belong to small businesses have employees under 500, a } \\
\text { few sectors of the manufacturing enterprise employees are less than } 750 \text { or } 1000 . \text { See } \\
\text { "Table of Small Business Standards Size" (2012). }\end{array}$ \\
\hline EU & $\begin{array}{l}\text { According to the definition of SMEs by the European Commission, medium-sized } \\
\text { enterprises employ less than } 250 \text { people, and the turnover of less than } 50 \text { million } \\
\text { euros; small businesses employ less than } 50 \text { people, and the turnover of not more than } \\
10 \text { million euros; micro enterprises employ less than } 10 \text { people, and the turnover of } \\
\text { less than } 2 \text { million euros. See "EU recommendation } 2003 / 361 / E C " \text { for details. }\end{array}$ \\
\hline
\end{tabular}


With the development of social economy, the classification standards of the small and medium-sized enterprise are constantly changing. According to the new classification standard of SMEs (Table1), China have about ten million small and medium-sized enterprises, the small enterprises accounted for $99.7 \%$ of the total number of businesses in the United States, European small and medium enterprises also accounted for all of enterprises $99 \%$. Due to the large number of SMEs, they play an important role in a country's economic development process, but also an important source of innovation.

\section{The Characteristics of SMEs' Innovation}

There are many differences between the small and medium-sized enterprises and the large enterprises except the number of employees. In the innovation research literature, an important topic is the importance of SMEs innovation relative to large enterprises. The role of SMEs in technological change and economic growth has been debated among economists. For example, Galbraith argues for the importance of large enterprises and monopoly power, that innovation needs a very high cost, only large companies have the appropriate resources for innovation [2]; and Schumaker is strongly advocated "small is beautiful" [3]. Some studies have shown that SMEs play an important role in innovation in the twentieth Century [4][5]. More research shows that small and medium-sized enterprises and large enterprises have advantages and disadvantages in innovation.

Many scholars compared the difference of the innovation between SMEs and large enterprise in many aspects [6][7][8] (Table 2), and indicated there was a big difference between SMEs and large enterprises in technological innovation [9][10].

Table 2 The innovation characteristics of SMEs and large enterprises

\begin{tabular}{|c|c|c|}
\hline & SMEs & Large enterprises \\
\hline Marketing & $\begin{array}{l}\text { Able to respond promptly to rapidly } \\
\text { changing market demands; closely } \\
\text { related to customers; an effective } \\
\text { market manipulator. }\end{array}$ & $\begin{array}{l}\text { Powerful channel and service } \\
\text { ability; existing products have } \\
\text { market power. }\end{array}$ \\
\hline Management & $\begin{array}{l}\text { The owner and the manager is usually } \\
\text { the same one; less bureaucracy and } \\
\text { management level, rapid decision } \\
\text { making; entrepreneurial managers can } \\
\text { respond quickly to the favorable } \\
\text { opportunity, and is willing to undertake } \\
\text { the risk. }\end{array}$ & $\begin{array}{l}\text { Owners and managers are usually } \\
\text { separated; professional managers } \\
\text { control complex organizations and } \\
\text { develop corporate strategies; formal } \\
\text { management skills. }\end{array}$ \\
\hline $\begin{array}{l}\text { Internal } \\
\text { communication }\end{array}$ & $\begin{array}{l}\text { Efficient informal internal information } \\
\text { communication network can quickly } \\
\text { solve the internal problems, and has } \\
\text { the ability to reorganize the } \\
\text { organization's external environment } \\
\text { changes. }\end{array}$ & $\begin{array}{l}\text { Internal communication is often not } \\
\text { smooth and leads to a slow } \\
\text { response to external opportunities } \\
\text { and threats. }\end{array}$ \\
\hline $\begin{array}{l}\text { Technical } \\
\text { personnel }\end{array}$ & $\begin{array}{l}\text { Often the lack of appropriate technical } \\
\text { specialists; often without the ability to } \\
\text { follow-up formal research and } \\
\text { development. }\end{array}$ & $\begin{array}{l}\text { An expert who can attract high } \\
\text { technology; a large research and } \\
\text { development laboratory. }\end{array}$ \\
\hline $\begin{array}{l}\text { External } \\
\text { communication }\end{array}$ & $\begin{array}{l}\text { Often lack of time or resources to } \\
\text { identify and use important external } \\
\text { resources (expertise in science and } \\
\text { Technology); the ability to absorb } \\
\text { knowledge is weaker. }\end{array}$ & $\begin{array}{l}\text { Able to maintain close contact with } \\
\text { external scientific, technological, } \\
\text { and specialized knowledge; provide } \\
\text { books and information services; } \\
\text { specialized research and } \\
\text { development specialists; able to } \\
\text { purchase critical technical } \\
\text { information and techniques. }\end{array}$ \\
\hline
\end{tabular}


Table 2 The innovation characteristics of SMEs and large enterprises (cont.)

\begin{tabular}{|c|c|c|}
\hline & SME & Large enterprise \\
\hline $\begin{array}{l}\text { Financial } \\
\text { resources }\end{array}$ & $\begin{array}{l}\text { It is difficult to attract capital (venture } \\
\text { capital); there is a great deal of } \\
\text { financial risk in innovation; risk can } \\
\text { not be dispersed through multiple } \\
\text { projects or portfolios. }\end{array}$ & $\begin{array}{l}\text { Able to obtain capital from the } \\
\text { capital market; capable of } \\
\text { dispersing risks through projects or } \\
\text { product combinations; able to } \\
\text { finance new products and new } \\
\text { markets. }\end{array}$ \\
\hline Scale economy & $\begin{array}{l}\text { In some economies of scale, there is a } \\
\text { huge barrier to entry for SMEs, and } \\
\text { there is no ability to provide a } \\
\text { complete product line and the entire } \\
\text { system. }\end{array}$ & $\begin{array}{l}\text { Able to build barriers to entry, } \\
\text { economies of scale for research, } \\
\text { production, and marketing; capable } \\
\text { of providing a range of related } \\
\text { products; capable of bidding for } \\
\text { "turnkey projects". }\end{array}$ \\
\hline Growth & $\begin{array}{l}\text { The difficulty of obtaining external } \\
\text { funds to meet rapidly growing needs; } \\
\text { entrepreneurial managers are often } \\
\text { unable to cope with and manage } \\
\text { increasingly complex organizations. }\end{array}$ & $\begin{array}{l}\text { Ability to fund expansion of } \\
\text { production scale; financial support } \\
\text { for diversification and mergers; the } \\
\text { ability to control complex } \\
\text { organizations. }\end{array}$ \\
\hline Patent & $\begin{array}{l}\text { Failing to deal with the patent } \\
\text { application department, there is not } \\
\text { enough time and cost involved in the } \\
\text { patent dispute. }\end{array}$ & $\begin{array}{l}\text { Able to employ specialists in } \\
\text { applying for patents; able to protect } \\
\text { patents by law and prevent } \\
\text { infringement. }\end{array}$ \\
\hline R\&D & Informal and temporary & Formal and planned \\
\hline $\begin{array}{l}\text { Government } \\
\text { regulation }\end{array}$ & $\begin{array}{l}\text { Generally, it is impossible to deal with } \\
\text { complex regulatory provisions; } \\
\text { compliance regulation is usually costly } \\
\text { for SMEs. }\end{array}$ & $\begin{array}{l}\text { It can provide legal support for } \\
\text { solving complex regulatory } \\
\text { regulations, and can disperse the } \\
\text { costs of regulation, and can provide } \\
\text { funding for } \mathrm{R} \& \mathrm{D} \text { activities to deal } \\
\text { with regulatory actions. }\end{array}$ \\
\hline
\end{tabular}

The advantages of large enterprises in innovation are capital and resources. Enterprise resources have a strong influence on innovation performance [11], large enterprises have more resources, have stronger market power. The competitive advantage in this area can be transformed into the performance of enterprise innovation. For example, large, resource rich enterprises can quickly build distribution channels to increase the sales of innovative products. An enterprise with a large amount of resources is also an important signal for customers, can reduce the uncertainty faced by customers facing innovation and make customers respond positively to innovative results.

Small and medium-sized enterprises also have a lot of advantages because of "small". The advantages of SMEs are entrepreneurship, flexibility and a quick response to change in the environment. Many SMEs are flexible and able to maintain close ties with customers and respond quickly to changes in technology and market trends. Small and medium enterprises usually communicate smoothly internally, with a dynamic and entrepreneurial management style [12]. At the same time, some studies have found that the average ability of technical personnel in SMEs is relatively high, and the average cost of enterprise innovation is cheaper than that of large enterprises. SMEs also explore new technology areas. Therefore, SME innovation is more effective and efficient [13].

On the other hand, many SMEs are not going to innovate at all. The researchers found that the difference between a small amount of innovative small and medium sized enterprises and many non-innovative SMEs [14], and that many factors hinders the small and medium-sized enterprise innovation in some literature. The lack of funds, management and marketing problems, lack of technicians, access to external information, difficult to deal with government regulation and other factors constrain the small and medium-sized enterprises' innovation [15]. The ability of SMEs to develop new products may be due to organizational and marketing constraints. Other studies have discussed cultural barriers such as reluctance to change, ignore processes, focus on short-term needs, lack of strategic vision and blame cultural contagion, etc. [16]. The main problem for SMEs is the 
lack of the attention to organizational management issues in innovation areas [17].

The advantages of innovation in small and medium enterprises bring opportunities for innovation, while disadvantages may hinder innovation activities. In different industries, because of the different degree of capital concentration, the innovation contribution of SMEs shows great difference. According to Freeman, Soete of the early research and analysis from 1949 to 1970, found that contributions of small enterprises in industrial sector [18]: in aerospace, automotive, dye, medicine, cement, glass, steel, aluminum, synthetic resin and shipbuilding, coal and gas and other high capital intensive industries, due to the small enterprise resource disadvantage, resulting in small enterprises of innovative contribution is small or zero, whether in scientific instruments, electronics, textile, carpet, textile machinery, paper and cardboard, leather and footwear, wood and furniture, construction and other relatively low capital intensive industry department, capital strength and development cost of many products is low, the new company cost less, resulting in small enterprises of innovative contribution is big or considerable.

\section{Conclusion}

According to the above, the advantages of innovation in SMEs include: flexible organization, less bureaucratic, making rapid reaction to the change of technology and market environment, rapid and efficient internal communication, business owners to participate in management, with entrepreneurial spirit, flat leadership style, which mainly belong to the "behavior advantages". The disadvantage is the lack of management skills (lack of plan, lack of authority, lack of support from functional expert), rely on individual entrepreneurs' survival; it is difficult to attract venture capital and bank loans, innovation project failures may lead to huge losses on financial, facing the high fixed cost in technology investment, it is difficult to attract skilled staff and upgrade the technical knowledge, which mainly belong to the "inferior resources".

\section{References}

[1]Rosenbusch, N., Brinckmann, J., Bausch, A. Is innovation always beneficial? A meta-analysis of the relationship between innovation and performance in SMEs. Journal of Business Venturing, 2011, 26(4), 441-457.

[2]Galbraith J K. American capitalism: The concept of countervailing power. Transaction Publishers, 1970.

[3]Schumaker, E. Small is beautiful. Economics as if People Mattered, 1973, 25.

[4]Oakey, R. P., Rothwell, R., Cooper, S., Oakey, R. The management of innovation in high-technology small firms: Innovation and regional development in Britain and the United States. London: Pinter, 1988.

[5]Rothwell, R. Industrial innovation: Success, strategy, trends. The Handbook of Industrial Innovation, 1994, 33-53.

[6]Kafouros, M. I., Buckley, P. J., Sharp, J. A., Wang, C. The role of internationalization in explaining innovation performance. Technovation, 2008, 28(1-2): 63-74.

[7]Vermeulen, P. A. M. Uncovering Barriers to Complex Incremental Product Innovation in Small and Medium-Sized Financial Services Firms. Journal of Small Business Management, 2005, 43(4): 432-452.

[8]González, X., Jaumandreu, J., Pazó, C. Barriers to innovation and subsidy effectiveness. The Rand Journal of Economics, 2005, 36(4): 930-950.

[9]Freel, M. S. Sectoral patterns of small firm innovation, networking and proximity. Research Policy, 2003, 32(5), 751-770.

[10] Winter, S. G. Schumpeterian competition in alternative technological regimes. Journal of Economic Behavior \& Organization, 1984, 5(3-4), 287-320.

[11] Narver J C, Slater S F. The effect of a market orientation on business profitability. The Journal of Marketing, 1990: 20-35. 
[12] Rothwell, R. Industrial innovation: success, strategy, trends. The Handbook of Industrial Innovation, 1994.

[13] Vossen, R. W. Relative strengths and weaknesses of small firms in innovation. International Small Business Journal, 1998, 16(3): 88-94.

[14]Hadjimanolis, A., Dickson, K. Innovation strategies of SMEs in Cyprus, a small developing country. International Small Business Journal, 2000, 18(4): 62-79.

[15] Freel, M. S. Barriers to product innovation in small manufacturing firms. International Small Business Journal, 2000, 18(2): 60-80.

[16] Filson, A., Lewis, A. Cultural issues in implementing changes to new product development process in a small to medium sized enterprise (SME). Journal of Engineering Design, 2000, 11(2): 149-157.

[17] Cobbenhagen, J. Successful innovation: Towards a new theory for the management of small and medium-sized enterprises. Edward Elgar Publishing, 2000.

[18] Freeman C, Soete L. The economics of industrial innovation. Psychology Press, 1997. 